๑) Clinical and Translational Medicine a SpringerOpen Journal

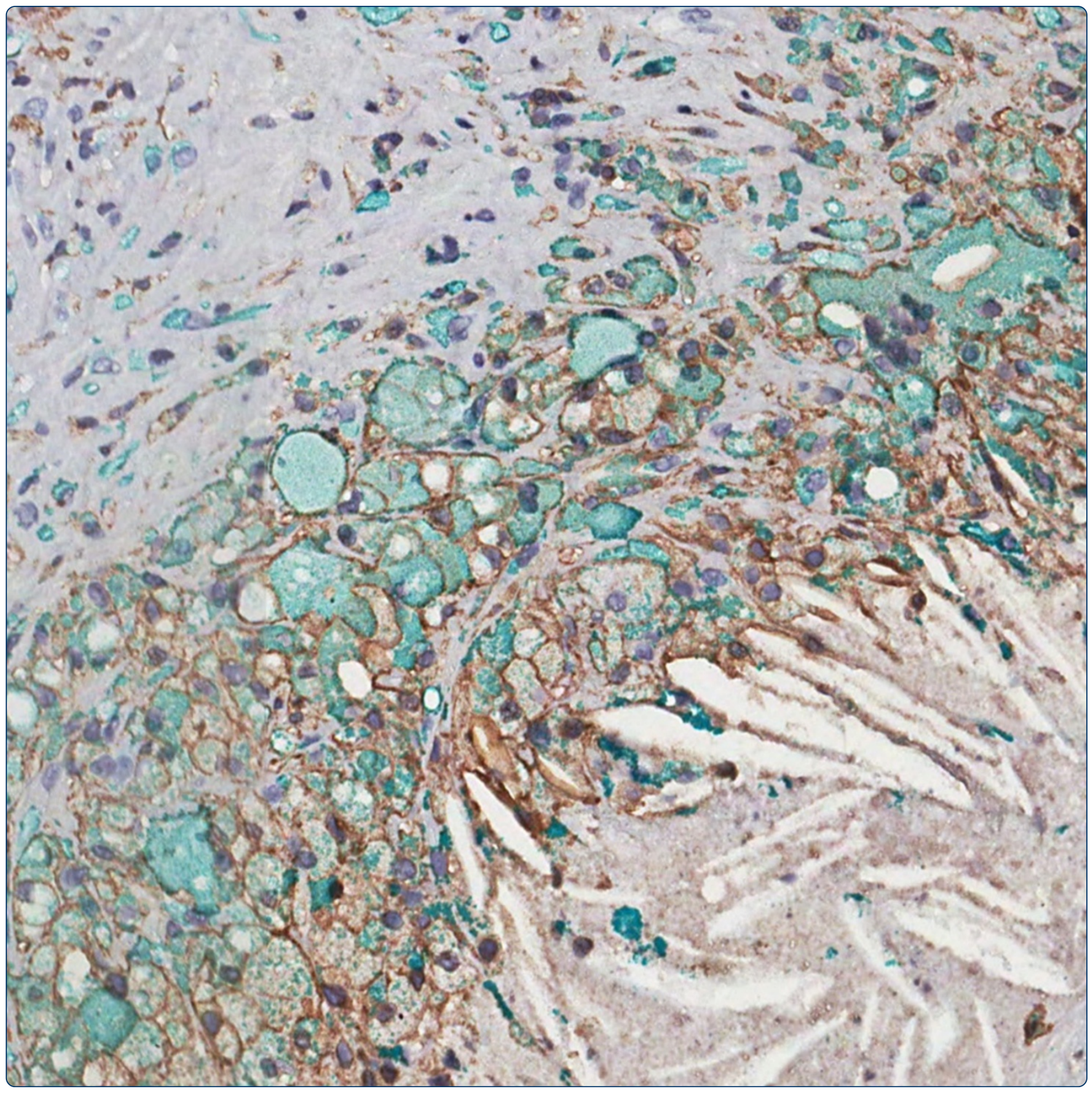

\title{
Clinical significance of macrophage phenotypes in cardiovascular disease
}

Medbury et al. 


\title{
Clinical significance of macrophage phenotypes in cardiovascular disease
}

\author{
Heather J Medbury*, Helen Williams and John P Fletcher
}

\begin{abstract}
The emerging understanding of macrophage subsets and their functions in the atherosclerotic plaque has led to the consensus that M1 macrophages are pro-atherogenic while M2 macrophages may promote plaque stability, primarily though their tissue repair and anti-inflammatory properties. As such, modulating macrophage function to promote plaque stability is an exciting therapeutic prospect. This review will outline the involvement of the different macrophage subsets throughout atherosclerosis progression and in models of regression. It is evident that much of our understanding of macrophage function comes from in vitro or small animal models and, while such knowledge is valuable, we have much to learn about the roles of the macrophage subsets in the clinical setting in order to identify the key pathways to target to possibly promote plaque stability.
\end{abstract}

Keywords: Macrophage; Cardiovascular disease; Atherosclerosis; Plaque stability; M1; M2; Review

\section{Introduction}

The main cause of cardiovascular disease is the formation of atherosclerotic plaques within the blood vessel wall. They may occur at multiple sites in the arterial tree and be at different stages of progression [1]. While plaques progressively narrow the arteries in which they form, their clinical significance is dependent more on their composition than the size they attain [2,3]. Morphologically, advanced plaques are composed of a necrotic core and overlying fibrous cap and those with a relatively large core and thin cap are considered unstable as they are vulnerable to rupture [2-4]. Rupture of the cap leads to exposure of the blood to thrombogenic material. While the subsequent thrombus that forms primarily leads to subclinical plaque progression, through fibrosis tissue formation and constrictive remodelling $[1,5]$, it may also lead to vessel occlusion and occurrence of a clinical event, such as a heart attack or stroke [6,7].

Macrophages are key players in atherosclerotic plaque development, progression and, importantly, stability as they contribute to formation of the core and degradation of the fibrous cap. However, macrophages can adopt various phenotypes including a wound healing form [8] and,

\footnotetext{
* Correspondence: heather.medbury@sydney.edu.au

Vascular Biology Research Centre, Department of Surgery, University of Sydney, Westmead Hospital, Westmead, NSW, Australia
}

indeed, collagen producing macrophages are present in human carotid plaques [9]. The 'plasticity' of macrophages gives hope to the notion of atherosclerotic plaque stabilisation through the modulation of macrophage functions. This review will summarise macrophage phenotype heterogeneity, the presence of the different 'subsets' within the plaque throughout its development and focus, in particular, on the possible clinical significance of macrophage subsets in terms of their likely contribution to plaque stability - such as their role in the core and cap.

\section{Review}

\section{Macrophage phenotypes}

Monocytes can differentiate into a spectrum of functional macrophage phenotypes depending upon the microenvironment - such as presence of specific growth and differentiation factors- as well as on the receptors they express, signaling pathways and transcription factors $[8,10]$. The first stage of differentiation is induced by macrophage colony stimulating factor (M-CSF) or granulocyte macrophage colony stimulating factor (GM-CSF) [11] and the subsequent phenotype that macrophages adopt is dependent upon the concentration of various mediators they are exposed to - with interferon (IFN)y and interleukin (IL)-4 priming macrophages to adopt classical or alternative 
phenotypes respectively [10]. Macrophages exhibit a high degree of plasticity such that some (though not all) of their properties alter as the local milieu changes [12-14].

Our understanding of macrophage phenotypes, and their plasticity, relies heavily on cell culture systems and, accordingly, so does much of the terminology applied to them. While numerous names have been used in the literature, the terms that predominate are M1 (classically activated) and M2 (alternatively activated) [15] and as such, these are used here. The M1 and M2 terms parallel the T helper cell (Th) 1 and Th2 cytokines which drive macrophage polarisation [16-19]. For a review on alternative nomenclature including differentiating based on activation method, the reader is directed to Murray et. al. [20].

M1 macrophages are promoted by Th1 cytokines [15], with this term used in the literature to describe macrophages induced by monocyte stimulation with GM-CSF $[21,22]$ or by M-CSF combined with lipopolysaccharide (LPS) and IFNY [23-25]. While the cytokine production from both these forms is similar [26], the current recommendation is that GM-CSF macrophages not be assigned the terminology M1 [20]. M1 macrophages are considered inflammatory as they produce high levels of IL-6 and TNF $\alpha[27,28]$ and they have a recognised role in tissue destruction [8]. M1 macrophages express proinflammatory transcription factors such as nuclear factor$\mathrm{KB}$ and signal transducer and activator of transcription (STAT) 1 [28-30].

The term 'M2' encompasses largely any phenotype that is not M1 [15,17] and is subdivided into groups based on the stimulus used, with M2a (alternative) stimulated by IL-4 or IL-13, M2b stimulated by immunocomplex and M2c stimulated by IL-10, glucocorticoids or transforming growth factor (TGF) $\beta$ [15,31-33]. The term 'M2' has also been used to describe M-CSF generated macrophages [34] with evidence that M-CSF stimulation promotes expression of a considerable portion of the M2 transcriptome [27]. M2 macrophages (human and mouse) produce anti-inflammatory cytokines such as IL-10 and TGF $\beta$ [27,35]. M2a macrophages express the transcription factors Krüppel-like factor 4, peroxisome proliferator activated receptor- $\gamma$ (PPAR $\gamma)$ and STAT6 [28-30] while M2c macrophages express STAT 3 [36]. The key recognised functions of M2 macrophages are immunosuppressive, including immune regulation and wound healing $[8,15,35]$. There are, in reality, many different modes of activation, resulting in an array of macrophage functional phenotypes [8]. The possible function of these subsets in plaque stability can, in part, be gleaned from understanding the effect of the stimulating cytokines on plaque development in murine models. As such, IFN $\gamma$ (which promotes M1) is considered pro-atherogenic, IL-4 (which promotes M2a) is considered to have a dual pro and anti-inflammatory character, while IL-10 (which promotes M2c macrophages), is considered anti-atherogenic [37].

In the atherosclerosis field, additional forms have been described including the Mhem macrophage [38] (also known $\mathrm{M}(\mathrm{Hb})$ [39] or HA-Mac [40]). Consistent with their presence in regions of haemorrhage, Mhem macrophages arise from culturing monocytes with the haemoglobin/ haptoglobin complex [38-40]. The term Mox macrophages has been given to murine macrophages (including M1 or M2) cultured in the presence of oxidised phospholipids [41]; their phenotype is markedly different from standard M1 or M2 macrophages. The term 'M4' describes macrophages formed when monocytes are differentiated with the platelet chemokine chemokine (C-X-C motif) ligand 4 (CXCL4) [42]. Other monocyte derived cells (sharing some overlapping functions with macrophages) are also recognised in the plaque, such as dendritic cells $[43,44]$ and fibrocytes [45]. Common markers used to identify the macrophage subsets include CD86 for M1 (as well as Arginase (Arg) II in mice) and CD163 plus CD206 (mannose receptor: MR) for M2 (as well as Arg I and FIZZ1 in mice) [15,24,27,31,46,47]. Transcriptome analysis of cultured cells has identified additional markers $[27,28,48]$. Noted differences are, that M2a macrophages also express CD209 [49]; Mhem macrophages, while expressing CD163 and CD206, are distinguishable from M2 macrophages by the expression of activating transcription factor (ATF) [38] and M4 macrophages lack expression of CD163 [50].

\section{Macrophages in plaque initiation}

Atherosclerosis is initiated by the accumulation of apolipoprotien (Apo) B lipoproteins within the vessel wall $[51,52]$. Their retention is partially mediated by interaction with extracellular matrix (ECM) proteins, primarily proteoglycans that have chondroitin sulphate side chains [52] such as biglycan and versican [53-55]. ECM binding makes lipoproteins susceptible to modification, such as oxidation $[56,57]$. This activates endothelial cells (EC) which secrete chemokines that promote monocyte recruitment $[58,59]$. Vascular cells, such as EC and smooth muscle cells (SMC), produce M-CSF - a factor which promotes monocyte differentiation into macrophages $[60,61]$. The macrophages formed internalise the modified low density lipoprotein (LDL), become foam cells [62] and form what is known as a fatty streak [63]. The inflammatory response to retained lipoproteins is maladapted as the macrophage foam cells do not leave but are retained in the vessel wall [52]. They may also exacerbate lesion formation independently by producing molecules such as lipoprotein lipase [64], sphingomyelinase [65] or proteoglycans [66], which promote lipoprotein retention and modification [67]. Though the contribution of different macrophage subsets to lipoprotein retention is not completely defined, M2a macrophages 
secrete components of the ECM as part of their wound healing function [8]. Our preliminary findings are that CD163+ foam cells in the plaque produce biglycan (unpublished data) and thus may contribute to retention of lipoproteins.

In the murine model (ApoE ${ }^{-/-}$mouse), it is thought that the early infiltrating macrophages are mainly of the M2 phenotype as they virtually all stain for Arg I [68]. Consistent with this, IL-4 was the predominant transcript (compared to IFN $\gamma$ ) in early lesions [68]. Furthermore, fatty streak formation is significantly reduced in IL- $4^{-/-}$mice [69]. Whether M2 macrophages predominate in early human plaques is not known, though M-CSFdriven monocyte to macrophage differentiation may promote such skewing (Figure 1). Inferences from the murine model are not entirely appropriate as the initial environment encountered by transmigrating monocytes is quite different to that in humans. There is minimal intima in the mouse [70], while human lesion-prone sites contain considerable diffuse intimal thickening (composed of SMC, elastin and proteoglycans) prior to lipid accumulation, with the lipid depositing deep in the (ECM and

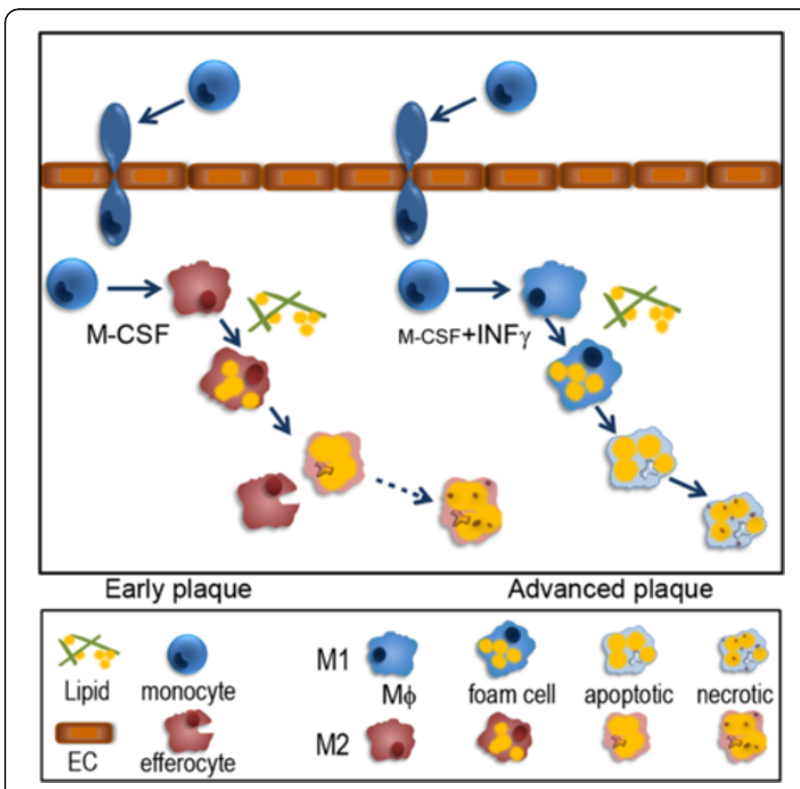

Figure 1 Proposed role of macrophage subsets in formation of the necrotic core. Monocytes are recruited early in atherosclerotic plaque development where, through the action of MCSF (and possibly IL-4, as evident in the mouse model), they differentiate into macrophages $(M \phi)$, primarily skewed towards an M2 form. Through the uptake of modified lipid they become foam cells. Apoptosis of the foam cells is accompanied by efferocytosis, primarily by $\mathrm{M} 2$ macrophages. As the plaque adopts an increasingly inflammatory environment, macrophage differentiation skews towards the $\mathrm{M} 1$ form and consequently, M1 foam cells predominate. As M1 macrophages have low efferocytosis capability, and there is a decreasing number of M2 efferocytes, apoptotic foam cells (including any remaining M2: dashed line in figure) undergo secondary necrosis promoting development of the necrotic core.
SMC rich) intima [71,72]. In humans, the foam cells form at the interface between infiltrating macrophages and extracellular lipid, rather than just below the luminal surface $[62,73]$. As the plaque progresses, a heterogeneous population of foam cells is found (Figure 2:A-C and F), as is evident by the presence of CD68+ foam cells that double stain with a variety of markers such as CD14 (M-CSF derived macrophages (M-Mac)) [74], CD86 (M1) [9], CD163(M2) [50] or MR (CD206:M2) [75] .

Conflicting data exists on the ability of different macrophage phenotypes to take up lipid with both increase and decrease of lipid uptake being reported in M2 macrophages- the differences are likely due to variations in culture conditions leading to differences in the cell types being formed and compared. While M2a macrophages take up less lipid than resting macrophages [75], M2 macrophages (a, b and c) take up more lipid than M1 macrophages (M-CSF with LPS plus IFN $\gamma$ ) [76]. M-CSF derived macrophages also take up more lipid than GM-CSF derived macrophages [34]. Macrophages can also take up lipid by non scavenger receptor means such as macropinocytosis [77]; interestingly, this is enhanced in M-CSF plus IL-10 (M2c) compared to GM-CSF derived macrophages [74]. The finding that M2 macrophages take up more lipid than M1 macrophages is consistent with the fact that M-CSF and IL-4 up-regulate the expression of CD36 [34,78] a receptor for oxLDL $[79,80]$ and scavenger receptor class A $[34,76]$ while, conversely, IFNy reduces CD36 expression [81]. GM-CSF up-regulates expression of genes that promote reverse cholesterol transport (PPAR $\gamma$, liver $x$ receptor (LXR)- $\alpha[34,74]$ and ATP-binding cassette sub-family G member 1(ABCG1)) [74]. As M2 (a, b and c) macrophages do not differ in ApoA-1 or high density lipoprotein (HDL)-stimulated cholesterol efflux compared with M1 macrophages, it is thought that the net increase in foam cell formation is primarily due to cholesterol uptake [76]. The accumulation of lipid by M-CSF derived macrophages enhances pro-inflammatory responses characterised by higher production of IL-6, IL-8 and MCP-1 and lower production of IL-10 upon stimulation with LPS [34].

As the atherosclerotic lesion progresses, a proinflammatory environment ensues with greater levels of Th1 cytokines (such as IFNY) compared to Th2 (IL-4) [7]. Consistent with this, lesion progression in the $\mathrm{ApoE}^{-/-}$ mouse is associated with an increased prevalence of M1 (Arg II) in older mice [68]. Thus, though M2 macrophages may theoretically have a greater ability to take up lipid in the plaque, the increasingly pro-inflammatory environment may skew monocyte to macrophage differentiation towards that of an M1 phenotype. This skewing would accordingly account for the reported absence of M2 foam cells in advanced human lesions [40], or their location distant from the core [75]. Though, interestingly, in the 


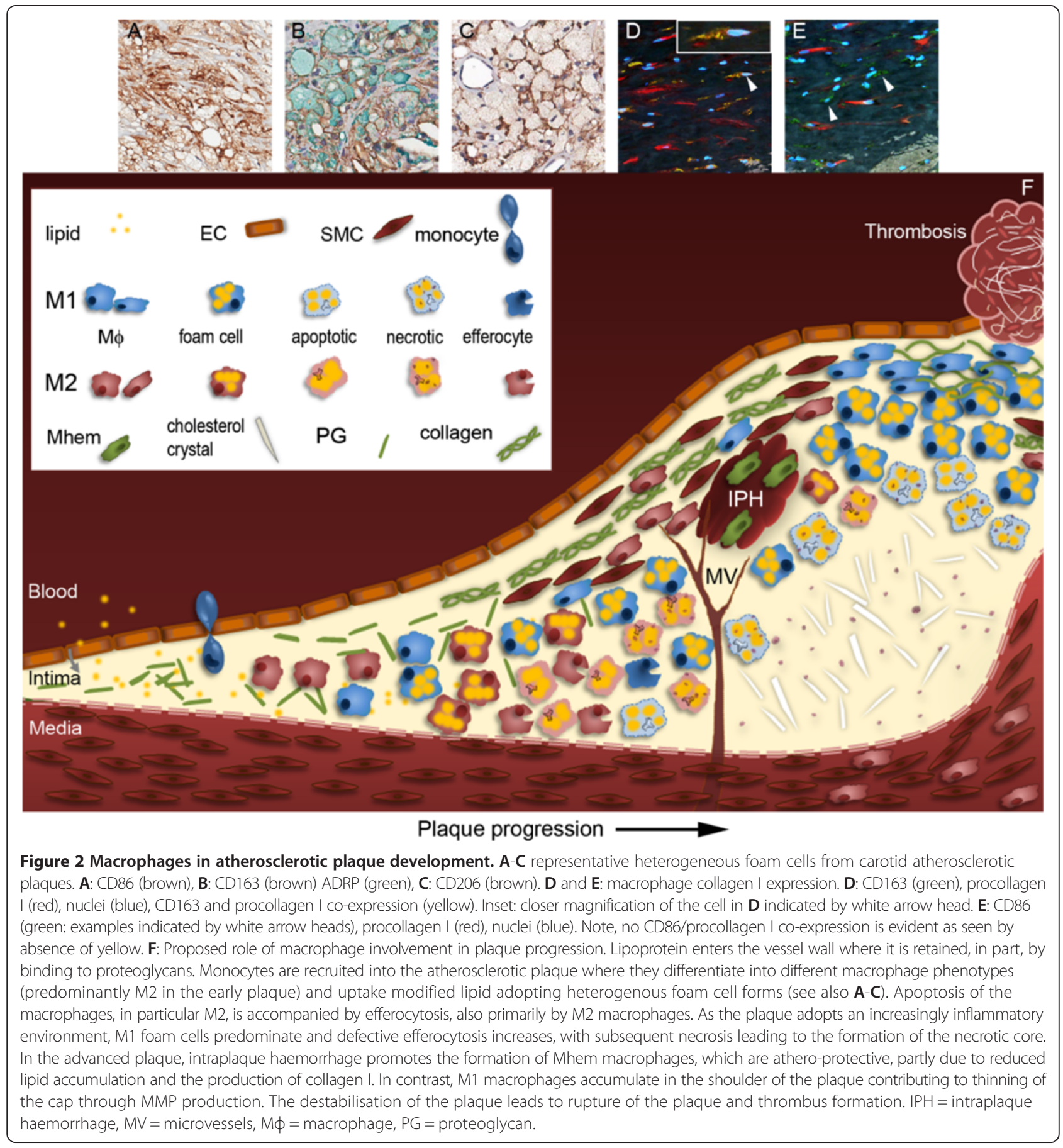

$\mathrm{ApoE}^{-1-}$ mouse, $\mathrm{M} 2(\mathrm{MR}+)$ macrophages were localised more centrally within the plaque, and had a higher proportion of adipose differentiation-related protein (ADRP) expression compared to M1(chemokine (C-C motif) receptor 7 (CCR7)) macrophages [82]. The lack of M2 foam cells may also arise from increased cell death, as cholesterol uptake promotes endoplasmic reticulum (ER) stress which triggers the unfolded protein response $[76,83]$ and M2 (IL-13 derived) foam cells are more sensitive to the unfolded protein response than other forms of macrophages [84].

\section{Macrophages and formation of the necrotic core}

The clearance of apoptotic cells promotes resolution of inflammation through the production of anti inflammatory mediators such as IL-10 and TGF $\beta$ [85-87]. However, in atherosclerosis, defective clearance of apoptotic cells leads to secondary necrosis and development of the 
necrotic core $[88,89]$. The switch from an M2 to an M1 promoting environment during atherosclerosis progression may impede apoptotic cell clearance as M2 cells have greater capacity for efferocytosis [90] (Figure 1); this is through various pathways such as the expression of MR [91] and up-regulation of MER proto-oncogene tryosine kinase (MERTK) (on M2c), which is not induced on M1 macrophages [49,92]. Furthermore, inhibition of autophagy promotes apoptosis and defective efferocytosis leading to increased plaque necrosis in a murine model [93]. Interestingly, ER stress, which promotes autophagy [93], also promotes an M2 macrophage phenotype [76], while mechanistic target of rapamcyin (mTOR) which negatively regulates autophagy [94], also inhibits M2 polarisation [95]. In addition, the uptake of phospholipid (and adoption of a Mox phenotype) reduces the ability of both M1 and M2 macrophages to phagocytose apoptotic cells [41]. Necrosis leads to a pro-inflammatory state, which itself promotes formation of efferocytic low macrophage phenotypes [90].

\section{Macrophages in the fibrous cap}

While a large necrotic core promotes plaque instability, formation of the fibrous cap promotes plaque stability and thus the role of macrophages in the cap is equally important. Both M1 (CD86) and M2 (CD163 and MR) macrophages are found in the atherosclerotic cap, where they adopt a spindle shape (Figure 2: D-F) $[9,96]$. A high number of CD68 macrophages in the cap is associated with plaque instability $[97,98]$, with this association also holding for M1(CD86), but not M2(CD163), macrophages [9]. Similarly, levels of CD68 and CD11c (M1) in the carotid plaque are higher in symptomatic patients compared to asymptomatic patients, while levels of the M2 markers (CD163 and MR) are lower [99]. Notably, M1 macrophages are found in the rupture-prone shoulder regions of the plaque [96]. Macrophage activity in the cap is highly detrimental as they produce matrix metalloproteinases (MMP) which degrade components of the matrix, thinning the cap and leaving it vulnerable to rupture [100-102]. That M1 macrophages are more frequent in plaques with an unstable morphology is consistent with the understanding that M1 macrophages are involved in tissue destruction [8]. This can be directly through the production of matrix metalloproteinases and indirectly through effects on SMC. Macrophage production of inflammatory cytokines, such as IL-1 and $\mathrm{TNF} \alpha$, can stimulate SMC to produce gelatinase, interstitial collagenase and stromelysin [103]. Furthermore, TNF $\alpha$ promotes macrophage-induced vascular SMC apoptosis [104], thus reducing the source of collagen and other matrix which thickens the cap. These cytokines also further activate EC and SMC, up-regulating chemokine production [105].
M2 macrophages may promote plaque stability due to their promotion of tissue repair and evidence of this in the carotid plaque is seen by their (CD163+ and CD206+ macrophages) production of collagen I (Figure 2:D) [9]. Despite this function however, no correlation was found in levels of CD163 in plaque cap, with cap thickness [9]; which may reflect a range of macrophages in the plaque that can express CD163. Furthermore, M2 macrophages may also promote plaque stabilisation by inducing the proliferation of vascular SMC [68].

\section{Macrophages in the complex plaque}

Advanced plaques can become quite complex with features such as calcification and intra-plaque haemorrhage. In this respect, distinct macrophages are found in regions of plaque haemorrhage displaying a non foam cell form [38-40]. In vitro investigation of these Mhem macrophages shows that they are resistant to foam cell formation through down regulation of scavenger receptors and up-regulation of ATP-binding cassette, sub-family A member 1 (ABCA1), ABCG1 [39] and LXR- $\beta$ [38]. Consistent with this, MR (CD206) + foam cells in the plaque are smaller and contain smaller lipid droplets than their MR-counterparts [75]. Mhem macrophages are thought to be athero-protective as haemoglobin binding to CD163 up-regulates haemoxygenase (HMOX)1 [106]. HMOX1 catabolises haeme, thus removing its pro-oxidative and pro- inflammatory actions, and in the process, promotes anti-oxidant and anti-inflammatory effects through the generation of haeme degradation byproducts, such as biliverdin [107]. Over-expression of HMOX1 inhibits atherosclerosis in $\mathrm{ApoE}^{-1-}$ mice [108]. With the production of collagen I evident in CD163+ and CD206+ macrophages found in regions of haemorrhage [9], this suggests that Mhem macrophages may also be athero-protective through production of collagen I. M4 macrophages are also evident in the plaque; they may have a pro-atherogenic role as CXCL4 deficiency results in decreased atherosclerotic plaque burden [109]. Furthermore, in vitro, CXCL4 down regulates both IL-10 secretion and CD163 expression and inhibits HMOX1 up-regulation [50].

\section{Macrophage phenotypes in plaque regression/stabilisation}

Plaque regression or stabilisation, a key clinical goal, has been achieved in mouse models, most notably in the Reversa mouse - a mouse in which hypercholesterolaemia (due to knock out of the LDL receptor) can be conditionally reversed [110]. Decreasing LDL resulted in stabilisation of the plaque with a reduced lipid component and increased collagen content. These changes were associated with a decrease in total macrophages $(\mathrm{CD} 68$ and Moma +$)$ and increased gene expression of 
M2 markers such as Arg I, MR, CD163, C-lectin and FIZZ1 [111]. This increase in M2 macrophages is also evident in other models of plaque regression including transplant of the atherosclerosed vessel into normal cholesterolaemic mice [112] and induction of regression by HDL [113]. Whether these changes involved a phenotypic conversion of M1 to M2 macrophages is not clear, but it has been suggested to occur in the $\mathrm{ApoE}^{-/-}$mouse as seen by the presence of macrophages double staining with Arg I (M2) and Arg II (M1) [68], though it should be noted that the specificity of Arg I for M2 macrophages is in question [20]. Nonetheless, an M1- M2 switch has been seen in other models, such as wound healing [114].

The polarisation towards an M2 phenotype in plaque regression is consistent with the view that M1 macrophages are pro-atherogenic and promote an unstable plaque, while M2 macrophages promote tissue repair [10] and likely plaque stability. Stimulation of the PPAR $\gamma$ pathway, which promotes M2 macrophage polarisation [115], results in decreased atherosclerosis development in the $\mathrm{ApoE}^{-/-}$mouse [116]. Interestingly, Wolfs et al. [117] observed reduced atherosclerosis in the $\mathrm{LDLR}^{-/-}$mouse after injection of helminth antigens which reprogrammed monocytes and macrophages to an M2 phenotype. Of note, a link between Schistosomal infection and reduced incidence of atherosclerosis has previously been recognised [118]. These results show that modulation towards an M2 phenotype may inhibit plaque progression, reflect plaque regression and holds promise that it may also promote plaque regression in an advanced plaque.

\section{Plasticity of macrophage phenotypes}

Though the plasticity of macrophages in vitro and in vivo, which suggests functional adaptivity, has been documented [12-14,119-121], the reversal of the phenotype does not always occur and may depend upon the state of macrophage differentiation. For example, while PPAR $\gamma$ activation primes monocytes to adopt an M2 phenotype, it does not influence M2 marker expression in M1 macrophages nor does it influence the expression of M2 markers in human atherosclerotic lesions [115]. Furthermore, while M-CSF and IL-10 promote the formation of an M2c macrophage and accordingly high levels of expression of MERTK and ability to clear apoptotic cells [49], chronic pre-exposure of the cells to IFN- $\gamma$ or IL-4 prior to exposure with IL-10 down regulates MERTK, leading instead to the cells up-regulating Fas (CD95) and undergoing apoptosis [92]. In addition, M-CSF was unable to significantly induce CD163 expression on monocytes pre-exposed to CXCL4 [50]. Clearly a greater understanding of macrophage function in the plaque, their plasticity (or lack thereof) and the pathways involved is required to ensure that a plaque stabilising form can be promoted.

\section{Conclusion}

A spectrum of macrophage phenotypes is present in the atherosclerotic plaque with each, in some way, impacting plaque stability. Given the association of M1 macrophages with plaque instability and their known role in tissue destruction, decreasing the levels of these macrophages in the plaque is a promising avenue for plaque stabilisation. However, promoting the elevation of M2 macrophages in the plaque is too simplistic and requires a greater understanding of the function of the various subsets within the human plaque and careful consideration of the pathways to target. For while M2 macrophages may have predominantly anti-atherogenic functions, some properties may promote plaque progression; such as their increased uptake of, and sensitivity to, oxLDL, which may promote enlargement of the core. Furthermore, while macrophages are 'plastic', it is apparent that such plasticity is quite conditional with some, but not all, properties being reversible and even leading to undesired functions. (Note also that the source of macrophages in the plaque; the contribution of monocyte derived, proliferating and resident macrophages, to plaque stability will also need to be considered, but this was outside the scope of this review).

Upon further investigation, modulating macrophage function to promote plaque stabilisation may become a reality. However, any approach to modulate macrophage phenotype should be an adjunct to existing treatments of lowering lipids, for lipid deposition in the arterial wall is a key initiating factor in atherosclerosis and itself increases the inflammatory nature of the plaque, which could counteract efforts to promote a less inflammatory environment.

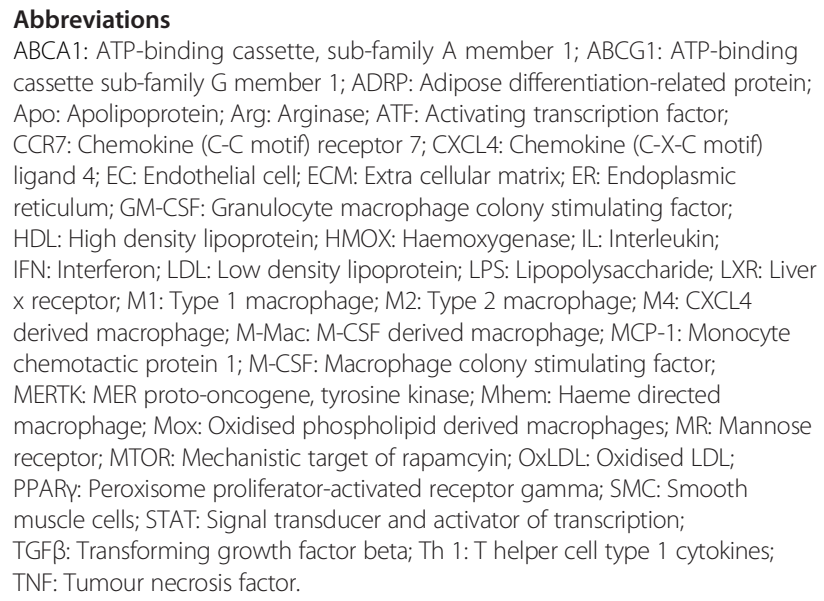

Competing interests

The authors declare they do not have any competing interests.

\section{Authors' contributions}

HM drafted the manuscript. Both HM and HW reviewed the literature. All authors read through and made suggestions and corrections to the manuscript. All authors approved the final manuscript. 


\section{Acknowledgments}

Thank you to Virginia James and Jessica Ngo who conducted the staining for the plaque pictures shown in this review.

Received: 30 September 2014 Accepted: 11 November 2014 Published online: 21 November 2014

\section{References}

1. Bentzon JF, Otsuka F, Virmani R, Falk E: Mechanisms of plaque formation and rupture. Circ Res 2014, 114:1852-1866.

2. Falk E, Shah PK, Fuster V: Coronary plaque disruption. Circulation 1995, 92:657-671.

3. Davies MJ, Richardson PD, Woolf N, Katz DR, Mann J: Risk of thrombosis in human atherosclerotic plaques: role of extracellular lipid, macrophage, and smooth muscle cell content. Br Heart J 1993, 69:377-381.

4. Kolodgie FD, Virmani R, Burke AP, Farb A, Weber DK, Kutys R, Finn AV, Gold HK: Pathologic assessment of the vulnerable human coronary plaque. Heart 2004, 90:1385-1391.

5. Braganza DM, Bennett MR: New insights into atherosclerotic plaque rupture. Postgrad Med J 2001, 77:94-98

6. Shah PK: Pathophysiology of coronary thrombosis: role of plaque rupture and plaque erosion. Prog Cardiovasc Dis 2002, 44:357-368.

7. Hansson GK, Libby P: The immune response in atherosclerosis: a double-edged sword. Nat Rev Immunol 2006, 6:508-519.

8. Mosser DM, Edwards JP: Exploring the full spectrum of macrophage activation. Nat Rev Immunol 2008, 8:958-969.

9. Medbury HJ, James V, Ngo J, Hitos K, Wang Y, Harris DC, Fletcher JP: Differing association of macrophage subsets with atherosclerotic plaque stability. Int Angiol 2013, 32:74-84.

10. Gordon S, Martinez FO: Alternative activation of macrophages: mechanism and functions. Immunity 2010, 32:593-604.

11. Stanley ER, Chen DM, Lin HS: Induction of macrophage production and proliferation by a purified colony stimulating factor. Nature 1978, 274:168-170.

12. Stout RD, Suttles J: Functional plasticity of macrophages: reversible adaptation to changing microenvironments. J Leukoc Biol 2004, 76:509-513.

13. Porcheray F, Viaud S, Rimaniol AC, Leone C, Samah B, Dereuddre-Bosquet N, Dormont D, Gras G: Macrophage activation switching: an asset for the resolution of inflammation. Clin Exp Immunol 2005, 142:481-489.

14. Stout RD, Jiang C, Matta B, Tietzel I, Watkins SK, Suttles J: Macrophages sequentially change their functional phenotype in response to changes in microenvironmental influences. J Immunol 2005, 175:342-349.

15. Martinez FO, Sica A, Mantovani A, Locati M: Macrophage activation and polarization. Front Biosci 2008, 13:453-461

16. Mills CD, Kincaid K, Alt JM, Heilman MJ, Hill AM: M-1/M-2 macrophages and the Th1/Th2 paradigm. J Immunol 2000, 164:6166-6173.

17. Mantovani A, Sozzani S, Locati M, Allavena P, Sica A: Macrophage polarization: tumor-associated macrophages as a paradigm for polarized M2 mononuclear phagocytes. Trends Immunol 2002, 23:549-555.

18. Modolell M, Corraliza IM, Link F, Soler G, Eichmann K: Reciprocal regulation of the nitric oxide synthase/arginase balance in mouse bone marrow-derived macrophages by TH1 and TH2 cytokines. Eur J Immunol 1995, 25:1101-1104.

19. Gratchev A, Schledzewski K, Guillot P, Goerdt S: Alternatively activated antigen-presenting cells: molecular repertoire, immune regulation, and healing. Skin Pharmacol Appl Skin Physiol 2001, 14:272-279.

20. Murray PJ, Allen JE, Biswas SK, Fisher EA, Gilroy DW, Goerdt S, Gordon S, Hamilton JA, Ivashkiv LB, Lawrence T, Locati M, Mantovani A, Martinez FO, Mege JL, Mosser DM, Natoli G, Saeij JP, Schultze JL, Shirey KA, Sica A, Suttles J, Udalova I, van Ginderachter JA, Vogel SN, Wynn TA: Macrophage activation and polarization: nomenclature and experimental guidelines. Immunity 2014, 41:14-20.

21. Verreck FA, de Boer T, Langenberg DM, Hoeve MA, Kramer M, Vaisberg E, Kastelein R, Kolk A, de Waal-Malefyt R, Ottenhoff TH: Human IL-23-producing type 1 macrophages promote but IL-10-producing type 2 macrophages subvert immunity to (myco)bacteria. Proc Natl Acad Sci U S A 2004, 101:4560-4565.

22. Verreck FA, de Boer T, Langenberg DM, van der Zanden $L$, Ottenhoff $T H$ : Phenotypic and functional profiling of human proinflammatory type-1 and anti-inflammatory type-2 macrophages in response to microbial antigens and IFN-gamma- and CD40L-mediated costimulation. J Leukoc Biol 2006, 79:285-293.
23. Leidi M, Gotti E, Bologna L, Miranda E, Rimoldi M, Sica A, Roncalli M, Palumbo GA, Introna M, Golay J: M2 macrophages phagocytose rituximab-opsonized leukemic targets more efficiently than $\mathrm{m} 1$ cells in vitro. J Immunol 2009, 182:4415-4422.

24. Lolmede K, Campana L, Vezzoli M, Bosurgi L, Tonlorenzi R, Clementi E, Bianchi ME, Cossu G, Manfredi AA, Brunelli S, Rovere-Querini P: Inflammatory and alternatively activated human macrophages attract vessel-associated stem cells, relying on separate HMGB1- and MMP-9-dependent pathways. J Leukoc Biol 2009, 85:779-787.

25. Rey-Giraud F, Hafner M, Ries $\mathrm{CH}$ : In vitro generation of monocyte-derived macrophages under serum-free conditions improves their tumor promoting functions. PLoS One 2012, 7:e42656.

26. Fleetwood AJ, Lawrence T, Hamilton JA, Cook AD: Granulocyte-macrophage colony-stimulating factor (CSF) and macrophage CSF-dependent macrophage phenotypes display differences in cytokine profiles and transcription factor activities: implications for CSF blockade in inflammation. J Immunol 2007, 178:5245-5252.

27. Martinez FO, Gordon S, Locati M, Mantovani A: Transcriptional profiling of the human monocyte-to-macrophage differentiation and polarization: new molecules and patterns of gene expression. J Immunol 2006, 177:7303-7311.

28. Xue J, Schmidt SV, Sander J, Draffehn A, Krebs W, Quester I, De Nardo D, Gohel TD, Emde M, Schmidleithner L, Ganesan H, Nino-Castro A, Mallmann MR, Labzin L, Theis H, Kraut M, Beyer M, Latz E, Freeman TC, Ulas T, Schultze $J$ : Transcriptome-based network analysis reveals a spectrum model of human macrophage activation. Immunity 2014, 40:274-288.

29. Hoeksema MA, Stoger $J$, de Winther MP: Molecular pathways regulating macrophage polarization: implications for atherosclerosis. Curr Atheroscler Rep 2012, 14:254-263.

30. Moore KJ, Sheedy FJ, Fisher EA: Macrophages in atherosclerosis: a dynamic balance. Nat Rev Immunol 2013, 13:709-721.

31. Stein M, Keshav S, Harris N, Gordon S: Interleukin 4 potently enhances murine macrophage mannose receptor activity: a marker of alternative immunologic macrophage activation. J Exp Med 1992, 176:287-292.

32. Mantovani A, Sica A, Sozzani S, Allavena P, Vecchi A, Locati M: The chemokine system in diverse forms of macrophage activation and polarization. Trends Immunol 2004, 25:677-686.

33. Sironi M, Martinez FO, D'Ambrosio D, Gattorno M, Polentarutti N, Locati M, Gregorio A, lellem A, Cassatella MA, Van Damme J, Sozzani S, Martini A, Sinigaglia F, Vecchi A, Mantovani A: Differential regulation of chemokine production by Fcgamma receptor engagement in human monocytes: association of CCL1 with a distinct form of M2 monocyte activation (M2b, Type 2). J Leukoc Biol 2006, 80:342-349.

34. van Tits $L$, Stienstra $R$, van Lent PL, Netea MG, Joosten LA, Stalenhoef AF: Oxidized LDL enhances pro-inflammatory responses of alternatively activated M2 macrophages: a crucial role for Kruppel-like factor 2. Atherosclerosis 2011, 214:345-349.

35. Edwards JP, Zhang X, Frauwirth KA, Mosser DM: Biochemical and functional characterization of three activated macrophage populations. J Leukoc Biol 2006, 80:1298-1307.

36. Wolfs IM, Donners MM, de Winther MP: Differentiation factors and cytokines in the atherosclerotic plaque micro-environment as a trigger for macrophage polarisation. Thromb Haemost 2011, 106:763-771.

37. Kleemann R, Zadelaar S, Kooistra T: Cytokines and atherosclerosis: a comprehensive review of studies in mice. Cardiovasc Res 2008, 79:360-376.

38. Boyle JJ, Johns M, Kampfer T, Nguyen AT, Game L, Schaer DJ, Mason JC, Haskard DO: Activating transcription factor 1 directs Mhem atheroprotective macrophages through coordinated iron handling and foam cell protection. Circ Res 2012, 110:20-33.

39. Finn AV, Nakano M, Polavarapu R, Karmali V, Saeed O, Zhao X, Yazdani S, Otsuka F, Davis T, Habib A, Narula J, Kolodgie FD, Virmani R: Hemoglobin directs macrophage differentiation and prevents foam cell formation in human atherosclerotic plaques. J Am Coll Cardiol 2012, 59:166-177.

40. Boyle JJ, Harrington HA, Piper E, Elderfield K, Stark J, Landis RC, Haskard DO: Coronary intraplaque hemorrhage evokes a novel atheroprotective macrophage phenotype. Am J Pathol 2009, 174:1097-1108.

41. Kadl A, Meher AK, Sharma PR, Lee MY, Doran AC, Johnstone SR, Elliott MR, Gruber F, Han J, Chen W, Kensler T, Ravichandran KS, Isakson BE, Wamhoff $B R$, Leitinger $\mathrm{N}$ : Identification of a novel macrophage phenotype that develops in response to atherogenic phospholipids via Nrf2. Circ Res 2010, 107:737-746. 
42. Gleissner CA: Macrophage phenotype modulation by CXCL4 in atherosclerosis. Front Physiol 2012, 3:1.

43. Bobryshev Y, Lord RS: S-100 positive cells in human arterial intima and in atherosclerotic lesions. Cardiovasc Res 1995, 29:689-696.

44. Bobryshev YV, Lord RS, Rainer S, Jamal OS, Munro VF: Vascular dendritic cells and atherosclerosis. Pathol Res Pract 1996, 192:462-467.

45. Medbury HJ, Tarran SL, Guiffre AK, Williams MM, Lam TH, Vicaretti M, Fletcher JP: Monocytes contribute to the atherosclerotic cap by transformation into fibrocytes. Int Angiol 2008, 27:114-123.

46. Hao NB, Lu MH, Fan YH, Cao YL, Zhang ZR, Yang SM: Macrophages in tumor microenvironments and the progression of tumors. Clin Dev Immunol 2012, 2012:948098.

47. Martinez FO, Gordon S: The M1 and M2 paradigm of macrophage activation: time for reassessment. F1000Prime Rep 2014, 6:13.

48. Beyer M, Mallmann MR, Xue J, Staratschek-Jox A, Vorholt D, Krebs W, Sommer D, Sander J, Mertens C, Nino-Castro A, Schmidt SV, Schultze JL: High-resolution transcriptome of human macrophages. PLoS One 2012, 7:e45466.

49. Zizzo G, Hilliard BA, Monestier M, Cohen PL: Efficient clearance of early apoptotic cells by human macrophages requires $\mathrm{M} 2 \mathrm{c}$ polarization and MerTK induction. J Immunol 2012, 189:3508-3520.

50. Gleissner CA, Shaked I, Erbel C, Bockler D, Katus HA, Ley K: CXCL4 downregulates the atheroprotective hemoglobin receptor CD163 in human macrophages. Circ Res 2010, 106:203-211.

51. Williams KJ, Tabas I: The response-to-retention hypothesis of early atherogenesis. Arterioscler Thromb Vasc Biol 1995, 15:551-561.

52. Tabas I, Williams KJ, Boren J: Subendothelial lipoprotein retention as the initiating process in atherosclerosis: update and therapeutic implications. Circulation 2007, 116:1832-1844.

53. Williams KJ: Arterial wall chondroitin sulfate proteoglycans: diverse molecules with distinct roles in lipoprotein retention and atherogenesis. Curr Opin Lipidol 2001, 12:477-487.

54. Khalil MF, Wagner WD, Goldberg IJ: Molecular interactions leading to lipoprotein retention and the initiation of atherosclerosis. Arterioscle Thromb Vasc Biol 2004, 24:2211-2218.

55. Chait A, Wight TN: Interaction of native and modified low-density lipoproteins with extracellular matrix. Curr Opin Lipidol 2000, 11:457-463.

56. Schwenke DC, Carew TE: Initiation of atherosclerotic lesions in cholesterol-fed rabbits. I. Focal increases in arterial LDL concentration precede development of fatty streak lesions. Arteriosclerosis 1989, 9:895-907.

57. Williams KJ, Tabas I: The response-to-retention hypothesis of atherogenesis reinforced. Curr Opin Lipidol 1998, 9:471-474.

58. Gerrity RG, Naito HK, Richardson M, Schwartz CJ: Dietary induced atherogenesis in swine. Morphology of the intima in prelesion stages. Am J Pathol 1979, 95:775-792.

59. Glass CK, Witztum JL: Atherosclerosis. The road ahead. Cell 2001, 104:503-516.

60. Clinton SK, Underwood R, Hayes L, Sherman ML, Kufe DW, Libby P: Macrophage colony-stimulating factor gene expression in vascular cells and in experimental and human atherosclerosis. Am J Pathol 1992, 140:301-316.

61. Smith JD, Trogan E, Ginsberg M, Grigaux C, Tian J, Miyata M: Decreased atherosclerosis in mice deficient in both macrophage colony-stimulating factor (op) and apolipoprotein E. Proc Natl Acad Sci U S A 1995, 92:8264-8268

62. Zaman AG, Helft G, Worthley SG, Badimon JJ: The role of plaque rupture and thrombosis in coronary artery disease. Atherosclerosis 2000, 149:251-266.

63. Stary HC: Changes in components and structure of atherosclerotic lesions developing from childhood to middle age in coronary arteries. Basic Res Cardiol 1994, 89(Suppl 1):17-32.

64. Pentikainen MO, Oksjoki R, Oorni K, Kovanen PT: Lipoprotein lipase in the arterial wall: linking LDL to the arterial extracellular matrix and much more. Arterioscler Thromb Vasc Biol 2002, 22:211-217.

65. Schissel SL, Schuchman EH, Williams KJ, Tabas I: Zn2 +-stimulated sphingomyelinase is secreted by many cell types and is a product of the acid sphingomyelinase gene. J Biol Chem 1996, 271:18431-18436.

66. Kaplan M, Aviram M: Macrophage plasma membrane chondroitin sulfate proteoglycan binds oxidized low-density lipoprotein. Atherosclerosis 2000, 149:5-17.

67. Williams KJ, Tabas I: Lipoprotein retention-and clues for atheroma regression. Arterioscler Thromb Vasc Biol 2005, 25:1536-1540.
68. Khallou-Laschet J, Varthaman A, Fornasa G, Compain C, Gaston AT, Clement M, Dussiot M, Levillain O, Graff-Dubois S, Nicoletti A, Caligiuri G: Macrophage plasticity in experimental atherosclerosis. PLOS One 2010, 5:e8852.

69. George J, Shoenfeld Y, Gilburd B, Afek A, Shaish A, Harats D: Requisite role for interleukin- 4 in the acceleration of fatty streaks induced by heat shock protein 65 or Mycobacterium tuberculosis. Circ Res 2000, 86:1203-1210.

70. Nakashima Y, Plump AS, Raines EW, Breslow JL, Ross R: ApoE-deficient mice develop lesions of all phases of atherosclerosis throughout the arterial tree. Arterioscler Thromb 1994, 14:133-140

71. Nakashima $Y$, Chen $Y X$, Kinukawa N, Sueishi K: Distributions of diffuse intimal thickening in human arteries: preferential expression in atherosclerosis-prone arteries from an early age. Virchows Arch 2002, 441:279-288.

72. Virmani R, Kolodgie FD, Burke AP, Farb A, Schwartz SM: Lessons from sudden coronary death: a comprehensive morphological classification scheme for atherosclerotic lesions. Arterioscler Thromb Vasc Biol 2000 20:1262-1275

73. Nakashima Y, Fujii H, Sumiyoshi S, Wight TN, Sueishi K: Early human atherosclerosis: accumulation of lipid and proteoglycans in intimal thickenings followed by macrophage infiltration. Arterioscler Thromb Vasc Biol 2007, 27:1159-1165.

74. Waldo SW, Li Y, Buono C, Zhao B, Billings EM, Chang J, Kruth HS: Heterogeneity of human macrophages in culture and in atherosclerotic plaques. Am J Pathol 2008, 172:1112-1126.

75. Chinetti-Gbaguidi G, Baron M, Bouhlel MA, Vanhoutte J, Copin C, Sebti Y, Derudas B, Mayi T, Bories G, Tailleux A, Haulon S, Zawadzki C, Jude B, Staels B: Human atherosclerotic plaque alternative macrophages display low cholesterol handling but high phagocytosis because of distinct activities of the PPARgamma and LXRalpha pathways. Circ Res 2011, 108:985-995.

76. Oh J, Riek AE, Weng S, Petty M, Kim D, Colonna M, Cella M, Bernal-Mizrachi C Endoplasmic reticulum stress controls M2 macrophage differentiation and foam cell formation. J Biol Chem 2012, 287:11629-11641.

77. Kruth HS, Jones NL, Huang W, Zhao B, Ishii I, Chang J, Combs CA, Malide D, Zhang WY: Macropinocytosis is the endocytic pathway that mediates macrophage foam cell formation with native low density lipoprotein. J Biol Chem 2005, 280:2352-2360.

78. Yesner LM, Huh HY, Pearce SF, Silverstein RL: Regulation of monocyte CD36 and thrombospondin-1 expression by soluble mediators. Arterioscler Thromb Vasc Biol 1996, 16:1019-1025.

79. Endemann G, Stanton LW, Madden KS, Bryant CM, White RT, Protter AA: CD36 is a receptor for oxidized low density lipoprotein. J Biol Chem 1993, 268:11811-11816.

80. Kunjathoor W, Febbraio M, Podrez EA, Moore KJ, Andersson L, Koehn S, Rhee JS, Silverstein R, Hoff HF, Freeman MW: Scavenger receptors class $\mathrm{A}-\mathrm{I} / \mathrm{II}$ and $\mathrm{CD} 36$ are the principal receptors responsible for the uptake of modified low density lipoprotein leading to lipid loading in macrophages. J Biol Chem 2002, 277:49982-49988.

81. Nakagawa T, Nozaki S, Nishida M, Yakub JM, Tomiyama Y, Nakata A, Matsumoto K, Funahashi T, Kameda-Takemura K, Kurata Y, Yamashita S, Matsuzawa Y: Oxidized LDL increases and interferon-gamma decreases expression of CD36 in human monocyte-derived macrophages. Arterioscler Thromb Vasc Biol 1998, 18:1350-1357.

82. Oh J, Riek AE, Weng S, Petty M, Kim D, Colonna M, Cella M, Bernal-Mizrachi $C$ : Endoplasmic reticulum stress controls M2 macrophage differentiation and foam cell formation. J Biol Chem 2012, 287(15):11629-11641.

83. Seimon T, Tabas I: Mechanisms and consequences of macrophage apoptosis in atherosclerosis. J Lipid Res 2009, 50(Suppl):S382-S387.

84. Isa SA, Ruffino JS, Ahluwalia M, Thomas AW, Morris K, Webb R: M2 macrophages exhibit higher sensitivity to oxLDL-induced lipotoxicity than other monocyte/macrophage subtypes. Lipids Health Dis 2011, $10: 229$.

85. Voll RE, Herrmann M, Roth EA, Stach C, Kalden JR, Girkontaite I: Immunosuppressive effects of apoptotic cells. Nature 1997, 390:350-351.

86. Fadok VA, Bratton DL, Konowal A, Freed PW, Westcott JY, Henson PM: Macrophages that have ingested apoptotic cells in vitro inhibit proinflammatory cytokine production through autocrine/paracrine mechanisms involving TGF-beta, PGE2, and PAF. J Clin Invest 1998, 101:890-898. 
87. Huynh ML, Fadok VA, Henson PM: Phosphatidylserine-dependent ingestion of apoptotic cells promotes TGF-beta1 secretion and the resolution of inflammation. J Clin Invest 2002, 109:41-50.

88. Schrijvers DM, De Meyer GR, Kockx MM, Herman AG, Martinet W: Phagocytosis of apoptotic cells by macrophages is impaired in atherosclerosis. Arterioscler Thromb Vasc Biol 2005, 25:1256-1261.

89. Tabas I: Macrophage death and defective inflammation resolution in atherosclerosis. Nat Rev Immunol 2010, 10:36-46.

90. Korns D, Frasch SC, Fernandez-Boyanapalli R, Henson PM, Bratton DL: Modulation of macrophage efferocytosis in inflammation. Front Immunol 2011, 2:57.

91. Nauta AJ, Raaschou-Jensen N, Roos A, Daha MR, Madsen HO, Borrias-Essers MC, Ryder LP, Koch C, Garred P: Mannose-binding lectin engagement with late apoptotic and necrotic cells. Eur J Immunol 2003, 33:2853-2863.

92. Zizzo G, Cohen PL: IL-17 stimulates differentiation of human anti-inflammatory macrophages and phagocytosis of apoptotic neutrophils in response to IL-10 and glucocorticoids. J Immunol 2013, 190:5237-5246.

93. Liao X, Sluimer JC, Wang Y, Subramanian M, Brown K, Pattison JS, Robbins J, Martinez J, Tabas I: Macrophage autophagy plays a protective role in advanced atherosclerosis. Cell Metab 2012, 15:545-553.

94. Sergin I, Razani B: Self-eating in the plaque: what macrophage autophagy reveals about atherosclerosis. Trends Endocrinol Metab 2014, 25:225-234.

95. Byles V, Covarrubias AJ, Ben-Sahra I, Lamming DW, Sabatini DM, Manning $\mathrm{BD}$, Horng T: The TSC-mTOR pathway regulates macrophage polarization. Nat Commun 2013, 4:2834.

96. Stoger JL, Gijbels MJ, van der Velden S, Manca M, van der Loos CM, Biessen EA, Daemen MJ, Lutgens E, de Winther MP: Distribution of macrophage polarization markers in human atherosclerosis. Atherosclerosis 2012, 225:461-468.

97. Jander S, Sitzer M, Schumann R, Schroeter M, Siebler M, Steinmetz H, Stoll G: Inflammation in high-grade carotid stenosis: a possible role for macrophages and T cells in plaque destabilization. Stroke 1998 29:1625-1630.

98. Tavora FR, Ripple M, Li L, Burke AP: Monocytes and neutrophils expressing myeloperoxidase occur in fibrous caps and thrombi in unstable coronary plaques. BMC Cardiovasc Disord 2009, 9:27.

99. Cho KY, Miyoshi H, Kuroda S, Yasuda H, Kamiyama K, Nakagawara J, Takigami M, Kondo T, Atsumi T: The phenotype of infiltrating macrophages influences arteriosclerotic plaque vulnerability in the carotid artery. J Stroke Cerebrovasc Dis 2013, 22:910-918.

100. Lendon CL, Davies MJ, Born GV, Richardson PD: Atherosclerotic plaque caps are locally weakened when macrophages density is increased. Atherosclerosis 1991, 87:87-90

101. Galis ZS, Sukhova GK, Kranzhofer R, Clark S, Libby P: Macrophage foam cells from experimental atheroma constitutively produce matrix-degrading proteinases. Proc Natl Acad Sci U S A 1995, 92:402-406.

102. Gough PJ, Gomez IG, Wille PT, Raines EW: Macrophage expression of active MMP-9 induces acute plaque disruption in apoE-deficient mice. J Clin Invest 2006, 116:59-69.

103. Galis ZS, Muszynski M, Sukhova GK, Simon-Morrissey E, Unemori EN, Lark MW, Amento E, Libby P: Cytokine-stimulated human vascular smooth muscle cells synthesize a complement of enzymes required for extracellular matrix digestion. Circ Res 1994, 75:181-189.

104. Boyle JJ, Weissberg PL, Bennett MR: Tumor necrosis factor-alpha promotes macrophage-induced vascular smooth muscle cell apoptosis by direct and autocrine mechanisms. Arterioscler Thromb Vasc Biol 2003, 23:1553-1558.

105. Butcher MJ, Galkina EV: Phenotypic and functional heterogeneity of macrophages and dendritic cell subsets in the healthy and atherosclerosis-prone aorta. Front Physiol 2012, 3:44.

106. Schaer CA, Schoedon G, Imhof A, Kurrer MO, Schaer DJ: Constitutive endocytosis of CD163 mediates hemoglobin-heme uptake and determines the noninflammatory and protective transcriptional response of macrophages to hemoglobin. Circ Res 2006, 99:943-950.

107. Jeney V, Balla G, Balla J: Red blood cell, hemoglobin and heme in the progression of atherosclerosis. Front Physiol 2014, 5:379.

108. Juan SH, Lee TS, Tseng KW, Liou JY, Shyue SK, Wu KK, Chau LY: Adenovirus-mediated heme oxygenase-1 gene transfer inhibits the development of atherosclerosis in apolipoprotein E-deficient mice. Circulation 2001, 104:1519-1525.
109. Sachais BS, Turrentine T, Dawicki McKenna JM, Rux AH, Rader D, Kowalska MA: Elimination of platelet factor 4 (PF4) from platelets reduces atherosclerosis in C57BI/6 and apoE-/- mice. Thromb Haemost 2007, 98:1108-1113.

110. Lieu HD, Withycombe SK, Walker Q, Rong JX, Walzem RL, Wong JS, Hamilton RL, Fisher EA, Young SG: Eliminating atherogenesis in mice by switching off hepatic lipoprotein secretion. Circulation 2003, 107:1315-1321.

111. Feig JE, Parathath S, Rong JX, Mick SL, Vengrenyuk Y, Grauer L, Young SG, Fisher EA: Reversal of hyperlipidemia with a genetic switch favorably affects the content and inflammatory state of macrophages in atherosclerotic plaques. Circulation 2011, 123:989-998.

112. Feig JE, Vengrenyuk $Y$, Reiser V, Wu C, Statnikov A, Aliferis CF, Garabedian MJ, Fisher EA, Puig O: Regression of atherosclerosis is characterized by broad changes in the plaque macrophage transcriptome. PLoS One 2012, 7:e39790.

113. Feig JE, Rong JX, Shamir R, Sanson M, Vengrenyuk Y, Liu J, Rayner K, Moore K, Garabedian M, Fisher EA: HDL promotes rapid atherosclerosis regression in mice and alters inflammatory properties of plaque monocyte-derived cells. Proc Natl Acad Sci U S A 2011, 108:7166-7171.

114. Lee S, Huen S, Nishio H, Nishio S, Lee HK, Choi BS, Ruhrberg C, Cantley LG: Distinct macrophage phenotypes contribute to kidney injury and repair. J Am Soc Nephrol 2011, 22:317-326.

115. Bouhlel MA, Derudas B, Rigamonti E, Dievart R, Brozek J, Haulon S, Zawadzki C, Jude B, Torpier G, Marx N, Staels B, Chinetti-Gbaguidi G: PPARgamma activation primes human monocytes into alternative $\mathrm{M} 2$ macrophages with anti-inflammatory properties. Cell Metab 2007, 6:137-143.

116. Calkin AC, Forbes JM, Smith CM, Lassila M, Cooper ME, Jandeleit-Dahm KA Allen TJ: Rosiglitazone attenuates atherosclerosis in a model of insulin insufficiency independent of its metabolic effects. Arterioscler Thromb Vasc Biol 2005, 25:1903-1909.

117. Wolfs IM, Stoger JL, Goossens P, Pottgens C, Gijbels MJ, Wijnands E, van der Vorst EP, van Gorp P, Beckers L, Engel D, Biessen EA, Kraal G, van Die I, Donners MM, de Winther MP: Reprogramming macrophages to an anti-inflammatory phenotype by helminth antigens reduces murine atherosclerosis. FASEB J 2014, 28:288-299.

118. Assaad-Khalil SH, Lachine N, Sidrak M, Amara F, Jacotot B, Fahmy MH: Immuno-metabolic factors in schistosomal hepatic fibrosis modulating atherogenesis. Ann Biol Clin (Paris) 1992, 50:697-701.

119. Shnyra A, Brewington R, Alipio A, Amura C, Morrison DC: Reprogramming of lipopolysaccharide-primed macrophages is controlled by a counterbalanced production of IL-10 and IL-12. J Immunol 1998, 160:3729-3736.

120. Hagemann T, Lawrence T, McNeish I, Charles KA, Kulbe H, Thompson RG, Robinson SC, Balkwill FR: "Re-educating" tumor-associated macrophages by targeting NF-kappaB. J Exp Med 2008, 205:1261-1268.

121. Duluc D, Corvaisier M, Blanchard S, Catala L, Descamps P, Gamelin E, Ponsoda S, Delneste $Y$, Hebbar M, Jeannin P: Interferon-gamma reverses the immunosuppressive and protumoral properties and prevents the generation of human tumor-associated macrophages. Int J Cancer 2009, 125:367-373.

doi:10.1186/s40169-014-0042-

Cite this article as: Medbury et al:: Clinical significance of macrophage phenotypes in cardiovascular disease. Clinical and Translational Medicine 2014 3:42.

\section{Submit your manuscript to a SpringerOpen ${ }^{\odot}$ journal and benefit from:}

- Convenient online submission

- Rigorous peer review

- Immediate publication on acceptance

- Open access: articles freely available online

- High visibility within the field

- Retaining the copyright to your article

Submit your next manuscript at $>$ springeropen.com 